\title{
SMOKING HABITS RELATED TO INJURY AND ABSENTEEISM IN INDUSTRY
}

\author{
BY \\ C. R. LOWE \\ From the Department of Social Medicine, University of Birmingham
}

In February, 1957, a mass radiography unit visited the General Electric Company Limited at Witton, Birmingham, and 7,680 employees (70 per cent. of the population) were $x$-rayed. As the employees attended for examination a smoking history was taken from them by the clerks of the unit. The data collected formed part of a larger survey of smoking habits in the Midlands, the results of which have already been published (Cross, McDowell, and Posner, 1957). Among the employees of the General Electric Company who were questioned there were 3,341 male workers who remained with the firm throughout the 12 months ended December 31, 1957. This paper examines the frequency of attendance at ambulance rooms for treatment of injury and the frequency of absenteeism among these men in relation to their smoking habits.

\section{Current Smoking Habits of the Factory WORKERS}

The smoking habits of these factory workers are summarized in Table $I$. Of the 3,341 men who were questioned, 63.7 per cent. said that they were cigarette smokers, 4.7 per cent. that they smoked only a pipe, 8.4 per cent. that although in the past they had smoked they were now non-smokers, and $23 \cdot 3$ per cent. that they had never smoked.

This picture is the end result of the interplay of age and secular trends. As men get older they smoke

TABLE I

SMOKING HABITS OF 3,341 MALE FACTORY WORKERS

\begin{tabular}{|c|c|c|c|c|c|c|c|}
\hline \multicolumn{2}{|c|}{ Non-smokers } & \multicolumn{5}{|c|}{ Smokers } & \multirow{3}{*}{ Total } \\
\hline \multirow{2}{*}{$\begin{array}{c}\text { Never } \\
\text { Smoked }\end{array}$} & \multirow{2}{*}{$\underset{\text { Up }}{\text { Given }}$} & \multirow{2}{*}{$\begin{array}{l}\text { Pipe } \\
\text { only }\end{array}$} & \multicolumn{4}{|c|}{ Cigarettes (per day) } & \\
\hline & & & $1-9$ & $10-19$ & $20-29$ & $\begin{array}{c}30 \\
\text { and } \\
\text { Over }\end{array}$ & \\
\hline 777 & 280 & 158 & 361 & 988 & 604 & 173 & 3,341 \\
\hline $23 \cdot 3$ & 8.4 & $4 \cdot 7$ & 10.8 & $29 \cdot 6$ & $18 \cdot 1$ & 5.2 & $\begin{array}{c}100 \\
\text { per cent. }\end{array}$ \\
\hline
\end{tabular}

more and young men to-day smoke more than their fathers did when they were the same age. These trends are shown in Fig. 1 (overleaf). The proportion of men who said they had at some time smoked regularly increased rapidly with age, reaching a peak at ages 45-54; thereafter it decreased-a clear indication of a secular increase in the proportion of smokers. On the other hand the proportion of pipe smokers and of those who had given up smoking increased regularly from the youngest to the oldest age group. As the result of these conflicting trends, the proportion of men who at the time of the survey were regular cigarette smokers fell off very considerably beyond the age group $45-54$, so much so that there were no more cigarette smokers over the age of 65 than there were in the age group 20-24. It is also true that older smokers smoke more than younger smokers and that young smokers to-day are smoking more than young smokers of a generation ago. In this sample the mean number of cigarettes smoked per day by smokers increased from about 10 at ages $15-19$ to nearly 20 at ages $34-44$, and thereafter declined to about 16 at ages 65 and over (Fig. 2, overleaf).

Clearly, information about the smoking habits of a population is of little value unless it is age standardized and the date on which it was collected is known.

\section{Attendance at Ambulance RoOms for Works INJURIES}

From records in the works medical department it was possible to find out how many times during the 12 months ended December 31, 1957, each of the 3,341 men had attended an ambulance room for treatment of an injury sustained at work. It should perhaps be mentioned here that from a surgical point of view the great majority of these injuries were trivial. They consisted for the most part of minor lacerations, contusions, abrasions, and 


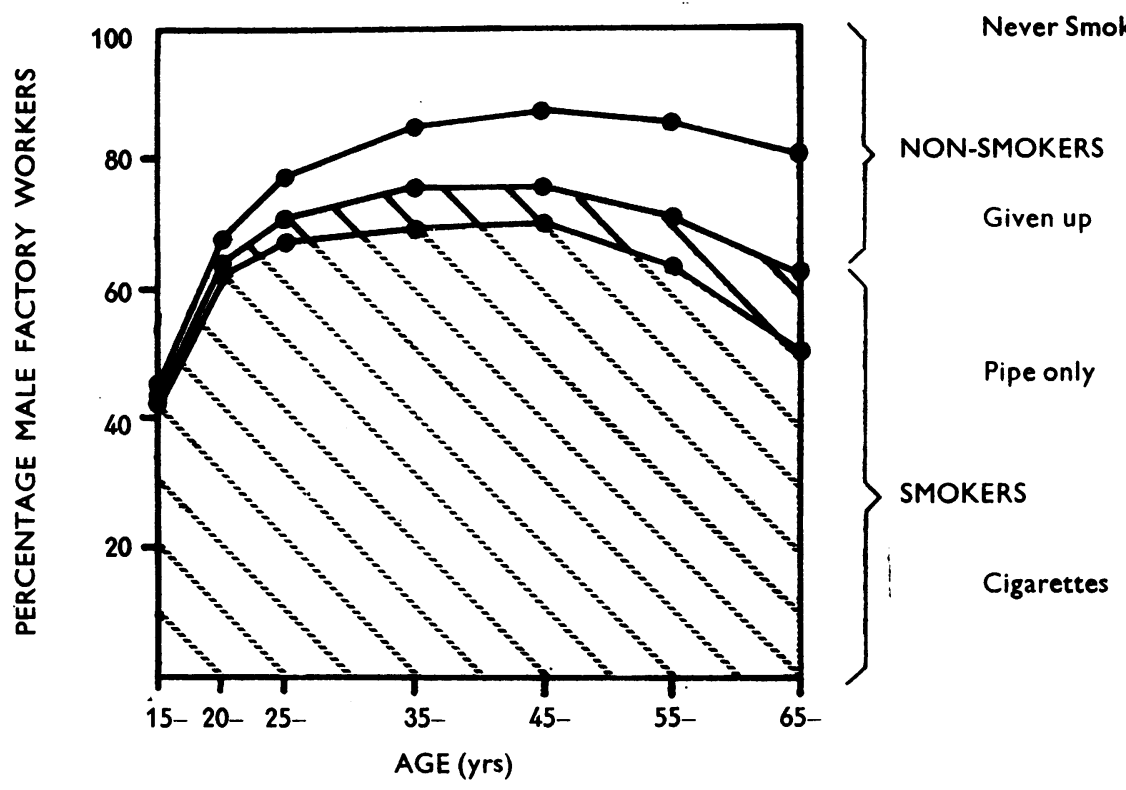

Fig. 1.-Smoking habits of factory workers related to age.

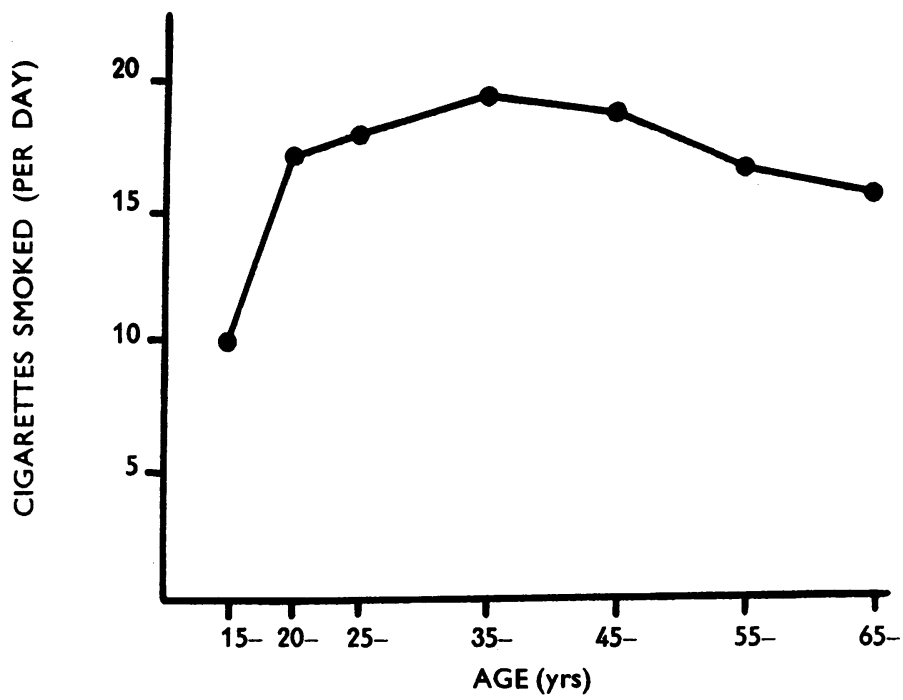

Fig. 2.-Number of cigarettes smoked por day by regular cigarette smokers, related to age.

puncture wounds of the hands and wrists, with a fair proportion of foreign bodies in the eye, foot injuries, and muscular strains. There were also of course a few serious injuries which required hospital treatment. The total number of attendances for works injury during the year was $6,838(2.05$ per worker) and the number of first attendances (i.e. the number of injuries treated) was $3,878(1 \cdot 17$ per worker). There is no doubt that some individuals are more accident prone than others, and a great deal has been written on the subject. It is of interest, therefore, that the distribution of treated injuries among the men was far from random. During the year 6.8 per cent. of them attended for five or more new injuries. If the 
distribution had followed the Poisson pattern, the expected proportion would have been $0 \cdot 8$ per cent. (Table II).

TABLE II

NUMBER OF WORKS INJURIES TREATED FOR 3,341 FACTORY WORKERS DURING 1957

\begin{tabular}{|c|c|c|c|c|c|c|c|}
\hline No. of Injuries. . & 0 & 1 & 2 & 3 & 4 & $\begin{array}{c}5 \\
\text { and } \\
\text { Over }\end{array}$ & Total \\
\hline No. of Workers & 1,848 & 665 & 298 & 187 & 115 & 228 & 3,341 \\
\hline $\begin{array}{l}\text { Percentage } \\
\text { Distribution }\end{array}$ & $55 \cdot 3$ & 19.9 & 8.9 & $5 \cdot 6$ & $3 \cdot 4$ & $6 \cdot 8$ & $\begin{array}{c}100 \\
\text { per cent. }\end{array}$ \\
\hline $\begin{array}{l}\text { Expected } \\
\text { (Poisson) } \\
\text { Distribution }\end{array}$ & $31 \cdot 0$ & $36 \cdot 3$ & $21 \cdot 2$ & $8 \cdot 3$ & $2 \cdot 4$ & 0.8 & $\begin{array}{c}100 \\
\text { per cent. }\end{array}$ \\
\hline
\end{tabular}

In Table III and Fig. 3 attendance at ambulance rooms for treatment of injuries is related to age. Both number of attendances and number of injuries treated per worker decreased with age. (For example, for the age group 15-24 there were 1.36 treated injuries per worker, while for the age group 55 and over the corresponding rate was only 0.83 ). This pattern is consistent with the findings of Newbold (1926) and others. But King and Speakman (1953) have pointed out that there are many inconsistencies in the literature, and the observation that in general accident rates appear to decline with age needs to be interpreted with caution. The finding is not unexpected in that young people who are incompletely

TABLE III

ATTENDANCE AT AMBULANCE ROOMS FOR INJURY RELATED TO AGE

\begin{tabular}{|c|c|c|c|c|c|c|}
\hline \multirow{2}{*}{$\begin{array}{l}\text { Injuries Treated } \\
\text { during } 1957\end{array}$} & \multicolumn{5}{|c|}{ Age (yrs) } & \multirow[b]{2}{*}{ Tota } \\
\hline & $15-24$ & $25-34$ & $35-44$ & $45-54$ & $\begin{array}{c}55 \\
\text { and } \\
\text { Over }\end{array}$ & \\
\hline $\begin{array}{l}\text { No. of Attendances } \\
\text { per Worker }\end{array}$ & $2 \cdot 27$ & $2 \cdot 18$ & $2 \cdot 09$ & $1 \cdot 84$ & $1 \cdot 59$ & $2 \cdot 05$ \\
\hline $\begin{array}{ccc}\text { No. of Injuries } & \text { per } \\
\text { Worker } & . . & . \\
\end{array}$ & $1 \cdot 36$ & $1 \cdot 26$ & $1 \cdot 18$ & 1.03 & 0.83 & $1 \cdot 17$ \\
\hline $\begin{array}{l}\text { No. of Attenda nces } \\
\text { per Injury }\end{array}$ & $1 \cdot 64$ & $1 \cdot 69$ & $1 \cdot 74$ & $1 \cdot 76$ & $1 \cdot 91$ & $1 \cdot 71$ \\
\hline Population .. & 700 & 834 & 836 & 555 & 416 & 3,341 \\
\hline
\end{tabular}

Attendances per worker Attendances per injury Injuries per worker
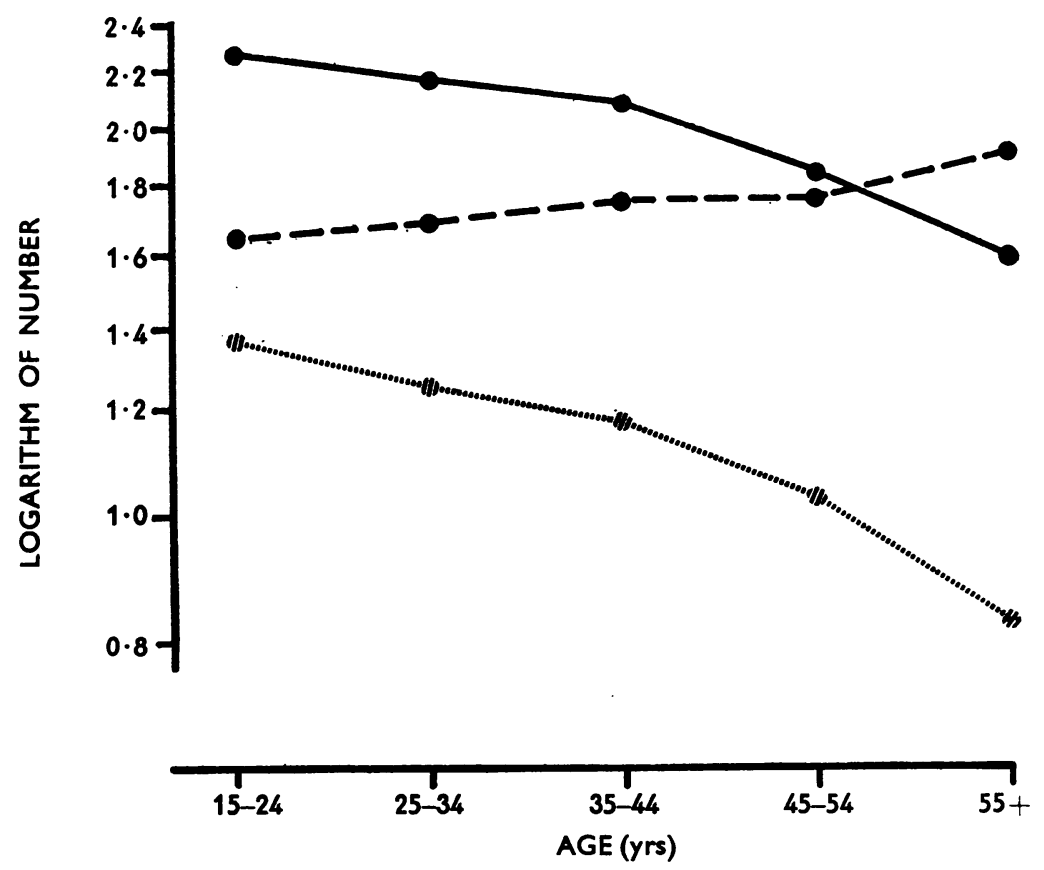

Fio. 3.-Attendances at ambulance room for injuries, related to age. 
trained easily become bored and sometimes behave irresponsibly-both skill and carefulness are attributes of ageing. On the other hand muscular power and visual and auditory acuity begin to decline in middle life, which might be expected to cause accident rates to increase. Complicating factors are the tendency for promotion to lead to occupations that are less hazardous and for older men to be moved on account of disability or failing powers to less dangerous jobs. Above all, it must be remembered that this investigation deals not with accident rates but with attendance at works ambulance rooms for treatment, and it is likely that an experienced worker would be less inclined to leave his job to seek treatment for a minor injury than a younger man. This is borne out by the observation that the number of attendances per injury (to some extent an index of severity) increased with age (Table III and Fig. 3).

\section{Absenteeism for MEdical and for Other Reasons}

In the works Labour Department a record was available of the number of working days lost by each man during 1957. It was possible to separate time lost for medical reasons (i.e. for which a doctor's note had been produced) from time lost for other reasons (i.e. for weddings, funerals, football matches, fishing expeditions, etc.). Some small part of the absence not covered by medical certificates (particularly in the shorter durations) was probably due to sickness. But it is likely that in general the distinction between the two types of absenteeism was reasonably accurate. During the year, the 3,341 workers lost between them 35,797 working days, 6.26 per man for medical reasons and 4.45 for other reasons. The distribution of the two types of absenteeism by number of days lost is shown in Table IV.

TABLE IV

ABSENTEEISM DURING 1957

\begin{tabular}{|c|c|c|c|c|c|c|c|c|}
\hline \multirow{2}{*}{\multicolumn{2}{|c|}{$\begin{array}{l}\text { Absenteeism } \\
\text { during } 1957\end{array}$}} & \multicolumn{6}{|c|}{ Number of Days Absent } & \multirow[b]{2}{*}{ Total } \\
\hline & & 0 & $1-4$ & $5-9$ & $10-14$ & $15-19$ & \begin{tabular}{|c|}
20 \\
and \\
Over
\end{tabular} & \\
\hline \multirow{2}{*}{$\begin{array}{l}\text { Medical } \\
\text { Reasons }\end{array}$} & $\begin{array}{l}\text { Number of } \\
\text { Workers }\end{array}$ & 1,180 & 1,060 & 495 & 241 & 110 & 255 & 3,341 \\
\hline & $\begin{array}{l}\text { Percentage } \\
\text { Distribution }\end{array}$ & $35 \cdot 4$ & $31 \cdot 7$ & $14 \cdot 8$ & $7 \cdot 2$ & $\mathbf{3} \cdot \mathbf{3}$ & $7 \cdot 6$ & 100 \\
\hline \multirow{2}{*}{$\begin{array}{l}\text { Other } \\
\text { Reansons }\end{array}$} & $\begin{array}{l}\text { Number of } \\
\text { Workers }\end{array}$ & 1,314 & 907 & 373 & 651 & 83 & 13 & 3,341 \\
\hline & $\begin{array}{l}\text { Percentage } \\
\text { Distribution }\end{array}$ & $39 \cdot 3$ & $27 \cdot 1$ & $11 \cdot 2$ & 19.5 & $2 \cdot 5$ & 0.4 & 100 \\
\hline
\end{tabular}

The pattern of absenteeism in relation to age is well known (Table V and Fig.4, opposite). The number of days lost for medical reasons increased with age from 4.8 per person at $15-24$ years to 10.0 per person at 55 years and over. This was due in the main to an increase with age in the proportion of men who were away for long periods, the proportion who lost no time at all during the year being little affected by age. There appeared to be no age trend in absenteeism for non-medical reasons.

\section{TABLE V}

ABSENTEEISM DURING 1957 RELATED TO AGE

\begin{tabular}{|c|c|c|c|c|c|c|c|}
\hline \multirow{2}{*}{\multicolumn{2}{|c|}{ Absenteeism during 1957}} & \multicolumn{5}{|c|}{ Age (yrs) } & \multirow[b]{2}{*}{ Total } \\
\hline & & $15-24$ & $25-34$ & $35-44$ & $45-54$ & $\left|\begin{array}{c}55 \\
\text { and } \\
\text { Over }\end{array}\right|$ & \\
\hline \multirow{3}{*}{$\begin{array}{l}\text { Medical } \\
\text { Reasons }\end{array}$} & $\begin{array}{c}\text { Days of Absence } \\
\text { per Worker }\end{array}$ & $4 \cdot 8$ & $5 \cdot 2$ & $5 \cdot 2$ & $8 \cdot 5$ & $10 \cdot 0$ & $6 \cdot 3$ \\
\hline & $\begin{array}{l}\text { Percentage of Work- } \\
\text { ers Absent for } 20 \\
\text { or More Days .. }\end{array}$ & $3 \cdot 3$ & $4 \cdot 8$ & $6 \cdot 2$ & $13 \cdot 5$ & $15 \cdot 6$ & $7 \cdot 6$ \\
\hline & $\begin{array}{c}\text { Percentage of Work- } \\
\text { ers who lost } \\
\text { Time }\end{array}$ & $35 \cdot 0$ & $30 \cdot 5$ & $39 \cdot 0$ & $39 \cdot 6$ & $32 \cdot 6$ & $35 \cdot 3$ \\
\hline $\begin{array}{l}\text { Other } \\
\text { Reasons }\end{array}$ & $\begin{array}{c}\text { Days of Absence } \\
\text { per Worker }\end{array}$ & $4 \cdot 1$ & $4 \cdot 8$ & $4 \cdot 5$ & $4 \cdot 4$ & $4 \cdot 3$ & $4 \cdot 5$ \\
\hline \multicolumn{2}{|c|}{ Population } & 700 & 834 & 836 & 555 & 416 & 3,341 \\
\hline
\end{tabular}

SMOKING Habits RELATEd TO INJURY AND ABSENTEEISM

It has been shown that frequency of attendance at ambulance rooms for injury decreased with age, absenteeism for medical reasons increased and absenteeism for other reasons was relatively unaffected, while the proportion of smokers at first rapidly increased but later decreased again. Obviously, to explore the relation between smoking habits and injury or absenteeism, age standardization is required.

When the men were classified in relation to both age and amount smoked, it was found that for each 10-year age group cigarette smokers had more injuries treated at the ambulance rooms than nonsmokers (Table VI, opposite)

In general, men who were heavy smokers also had more injuries treated than light smokers, but owing to small numbers in some of the age and smoking categories, the pattern was irregular. However, when injury treatment rates for the six smoking categories were age standardized (by applying the age-specific rates in each category to the age distribution of the total population), they showed a regular increase from non-smokers through light smokers to heavy smokers (Table VII, opposite). A similar trend was apparent in absenteeism for medical reasons, but there was no clear relationship 


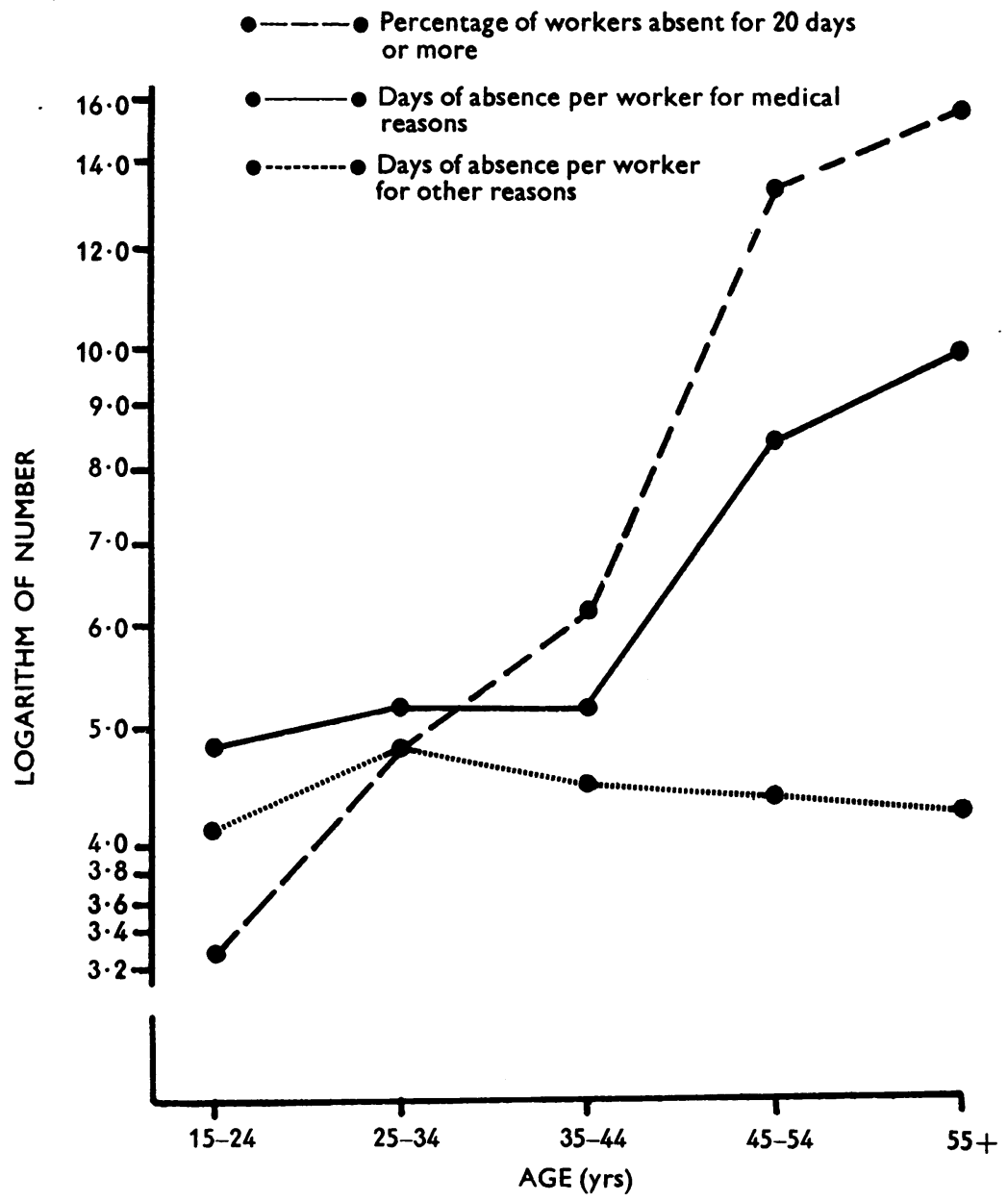

Fig. 4.-A Absenteeism related to age.

TABLE VI

NUMBER OF INJURIES TREATED PER WORKER RELATED TO AGE AND SMOKING HABITS

\begin{tabular}{|c|c|c|c|c|c|c|c|}
\hline \multirow{3}{*}{$\begin{array}{c}\text { Age } \\
\text { (yrs) }\end{array}$} & \multirow{3}{*}{$\begin{array}{l}\text { Non- } \\
\text { smokers }\end{array}$} & \multicolumn{5}{|c|}{ Smokers } & \multirow{3}{*}{ Total } \\
\hline & & \multirow{2}{*}{$\begin{array}{l}\text { Pipe } \\
\text { Only }\end{array}$} & \multicolumn{4}{|c|}{ Cigarettes (per day) } & \\
\hline & & & $1-9$ & $10-19$ & $20-29$ & $\begin{array}{l}30 \text { or } \\
\text { More }\end{array}$ & \\
\hline $15-24$ & $\begin{array}{l}1 \cdot 23 \\
(344)\end{array}$ & $\begin{array}{c}0.75 \\
(8)\end{array}$ & $\begin{array}{l}1 \cdot 29 \\
(119)\end{array}$ & $\begin{array}{l}1 \cdot 64 \\
(170)\end{array}$ & $\begin{array}{r}1 \cdot 51 \\
(55)\end{array}$ & $\begin{array}{c}2 \cdot 75 \\
(4)\end{array}$ & $\begin{array}{r}1 \cdot 36 \\
(700)\end{array}$ \\
\hline $25-34$ & $\begin{array}{l}1 \cdot 06 \\
(249)\end{array}$ & $\begin{array}{c}1 \cdot 12 \\
(26)\end{array}$ & $\begin{array}{l}1 \cdot 32 \\
(79)\end{array}$ & $\begin{array}{l}1.42 \\
(282)\end{array}$ & $\begin{array}{l}1 \cdot 36 \\
(151)\end{array}$ & $\begin{array}{l}1 \cdot 09 \\
(47)\end{array}$ & $\begin{array}{l}1 \cdot 26 \\
(834)\end{array}$ \\
\hline $35-44$ & $\begin{array}{l}1 \cdot 11 \\
(202)\end{array}$ & $\begin{array}{r}1 \cdot 31 \\
(55)\end{array}$ & $\begin{array}{r}1 \cdot 23 \\
(65)\end{array}$ & $\begin{array}{l}1 \cdot 02 \\
(238)\end{array}$ & $\begin{array}{l}1 \cdot 11 \\
(212)\end{array}$ & $\begin{array}{r}1 \cdot 39 \\
(64)\end{array}$ & $\begin{array}{l}1 \cdot 13 \\
(836)\end{array}$ \\
\hline $45-54$ & $\begin{array}{l}0.92 \\
(135)\end{array}$ & $\begin{array}{r}0.97 \\
(32)\end{array}$ & $\begin{array}{c}1 \cdot 02 \\
(43)\end{array}$ & $\begin{array}{l}1.03 \\
(187)\end{array}$ & $\begin{array}{l}1 \cdot 24 \\
(118)\end{array}$ & $\begin{array}{r}0.95 \\
(40)\end{array}$ & $\begin{array}{l}1.03 \\
(555)\end{array}$ \\
\hline $\begin{array}{l}55 \text { and } \\
\text { Over }\end{array}$ & $\begin{array}{l}0 \cdot 80 \\
(127)\end{array}$ & $\begin{array}{c}1.00 \\
(37)\end{array}$ & $\begin{array}{c}0.93 \\
(55)\end{array}$ & $\begin{array}{l}0 \cdot 73 \\
(111)\end{array}$ & $\begin{array}{l}0 \cdot 71 \\
(68)\end{array}$ & $\begin{array}{l}1 \cdot 50 \\
(18)\end{array}$ & $\begin{array}{l}0.83 \\
(416)\end{array}$ \\
\hline
\end{tabular}

TABLE VII

ABSENTEEISM AND INJURY (AGE STANDARDIZED) RELATED TO SMOKING HABITS

\begin{tabular}{|c|c|c|c|c|c|c|c|}
\hline \multirow{3}{*}{$\begin{array}{c}\text { Absenteeism and } \\
\text { Injury during } \\
1957\end{array}$} & \multirow{3}{*}{$\begin{array}{l}\text { Non- } \\
\text { smokers }\end{array}$} & \multicolumn{5}{|c|}{ Smokers } & \multirow{3}{*}{ Total } \\
\hline & & \multirow{2}{*}{$\begin{array}{l}\text { Pipe } \\
\text { only }\end{array}$} & \multicolumn{4}{|c|}{ Cigarettes (per day) } & \\
\hline & & & $1-9$ & $|10-19|$ & $20-29$ & $\begin{array}{c}30 \\
\text { and } \\
\text { over }\end{array}$ & \\
\hline $\begin{array}{l}\text { No. of Injuries } \\
\text { Treated per Worker }\end{array}$ & $1 \cdot 05$ & 1.05 & $1 \cdot 19$ & $1 \cdot 22$ & $1 \cdot 23$ & $1 \cdot 54$ & $1 \cdot 16$ \\
\hline $\begin{array}{l}\text { No. of Days Ab- } \\
\text { sence per Worker } \\
\text { for Medical Rea- } \\
\text { sons } \quad \text {.. }\end{array}$ & $5 \cdot 49$ & $6 \cdot 39$ & $6 \cdot 11$ & $6 \cdot 20$ & $6 \cdot 92$ & $8 \cdot 63$ & $6 \cdot 26$ \\
\hline $\begin{array}{l}\text { No. of Days Ab- } \\
\text { sence per Worker } \\
\text { for Other Reasons }\end{array}$ & $4 \cdot 32$ & $4 \cdot 02$ & $4 \cdot 51$ & $4 \cdot 34$ & $5 \cdot 13$ & $4 \cdot 52$ & $4 \cdot 45$ \\
\hline Population & 1,057 & 158 & 361 & 988 & 604 & 173 & 3,341 \\
\hline
\end{tabular}


between smoking habits and absenteeism for other reasons. The number of pipe smokers (198) was too small to permit any firm conclusion to be drawn about them, so they have been excluded from Fig. 5 which summarizes these findings.

As already mentioned, the works population was too small to permit the calculation of useful absentee and injury rates for different smoking categories within a narrow age range. It was apparent, however, that the relation between smoking and injury was more pronounced among the younger men, and the relation between smoking and absenteeism for medical reasons was largely confined to the older men. Fig. 6 compares the experience of men aged under 35 with that of men aged 35 and over. (Within these two broad age groups absentee and injury rates were standardized both for age and for number of cigarettes smoked by the cigarette smokers). It indicates that with regard to treated injuries there was no great difference between older cigarette smokers and non-smokers, but among the younger men the annual rate was 27 per cent. higher for the smokers. On the other hand, for medical absenteeism the picture was reversed: there was no appreciable difference among the younger men, but among the older men absenteeism was 34 per cent. higher for cigarette smokers than for non-smokers.

\section{Discussion}

Among 3,341 male factory workers absenteeism for non-medical reasons appeared to be unrelated to smoking habits; absenteeism for medical reasons

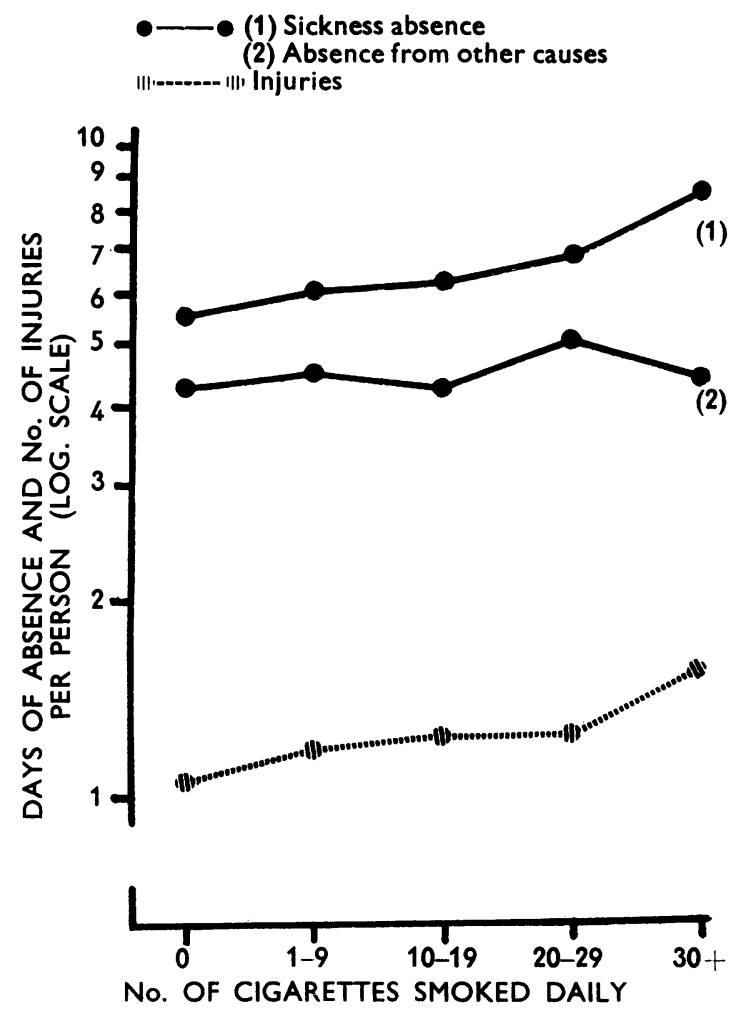

FIG. 5.-Absenteeism and attendances for injury related to smoking habits.

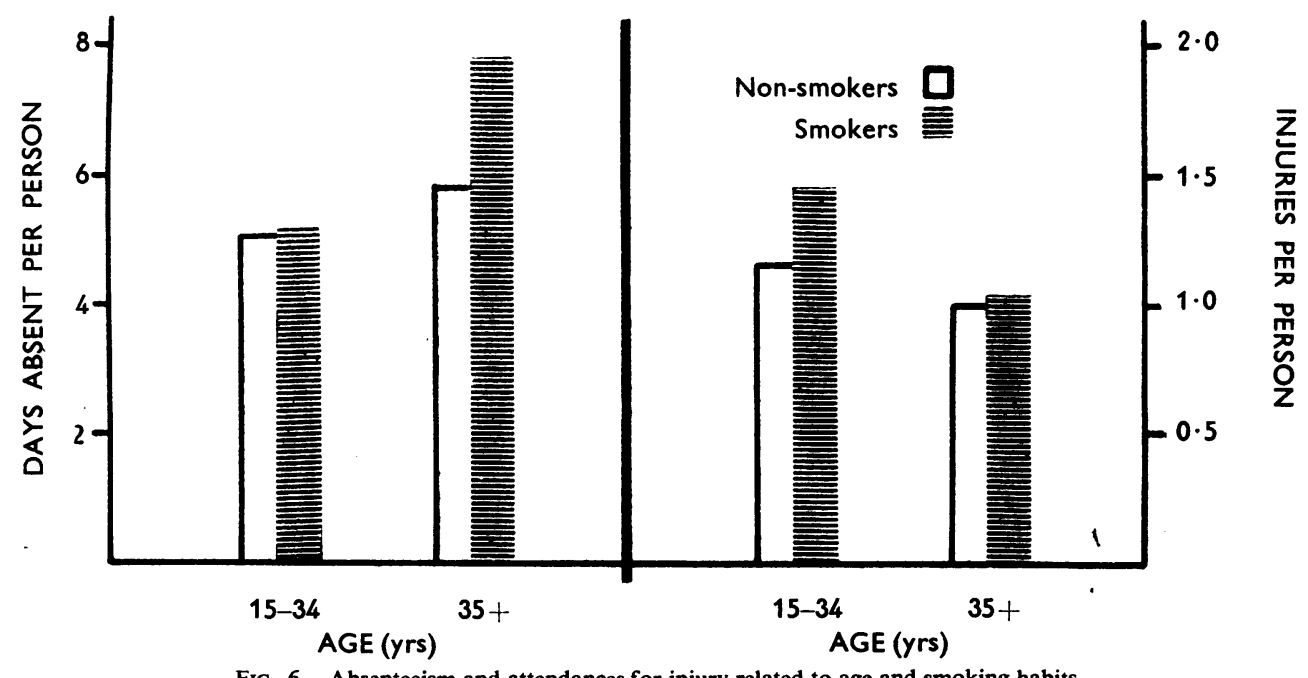

FIG. 6.-Absenteeism and attendances for injury related to age and smoking habits. 
and frequency of attendance for treatment of injury were both higher for cigarette smokers than for nonsmokers and increased fairly regularly with amount smoked. The relationship between smoking and medical absenteeism affected mainly older workers, and, in view of the known association between smoking and disease, would have been expected. The relationship between smoking and attendance for injury affected chiefly younger workers and would not perhaps have been anticipated. Nevertheless it is not difficult to suggest a possible explanation for this finding. Although it is conceivable that tobacco smoke has a pharmacological effect upon muscular co-ordination, it seems more likely that young people who smoke heavily are temperamentally more accident prone (or more likely to attend for treatment of minor injuries) than those who are light smokers or non-smokers.

These observations are of no great practical significance in relation to absenteeism and injury in industry, but they have a bearing on the smoking controversy. The central question is whether cigarette smoking is a direct cause of lung cancer and the other diseases with which it is consistently found to be associated. It has been suggested that the relationships may be attributable to genetic susceptibility-for example that certain people may inherit both a predisposition to lung cancer and a predisposition to smoke cigarettes (Fisher, 1959). At first sight the observation that accident rates are higher for smokers than for non-smokers might appear to support this view, for it seems reasonable to believe that there is a genetic basis for both accident proneness and the tendency to smoke. It does not follow, however, that it is also reasonable to suppose that smoking and cancer of the lung are linked through genetic susceptibility. The diseases with which smoking has been shown to be associated-lung cancer, chronic bronchitis, coronary artery disease, peptic ulcer, and respiratory tuberculosis-are limited to those in which it was suggested as an aetiological agent long before a statistical association was established. The common sense which accepts a genetic link between smoking and accidents would reject it in the case of diseases in which another and more plausible explanation is available.

\section{SUMMARY}

This paper examines the frequency of attendance at ambulance rooms for treatment of injury and of absenteeism among 3,341 male factory workers in relation to their smoking habits.

Frequency of attendance for treatment of injury decreased with age. It was higher among smokers than non-smokers and increased fairly regularly with amount smoked. The relationship to smoking was more pronounced among younger than among older workers.

Absenteeism for medical reasons increased with age. It was higher among smokers than non-smokers and increased with amount smoked. The relationship to smoking was more pronounced among older than among younger workers.

Absenteeism for non-medical reasons did not appear to be related to age or to smoking habits.

The bearing of these observations on the smoking controversy is discussed.

\section{REFERENCES}

Cross, K. W., McDowell, L. A., and Posner, E. (1958). Brit. med. J., $1,862$.

Fisher, R. A. (1959). “Smoking: the Cancer Controversy”. Oliver and Boyd, Edinburgh.

King, H. F., and Speakman, D. (1953). Brit. J. industr. Med., 10, 51.

Newbold, E. M. (1926). Industrial Fatigue Research Board. Report No. 34 (Med. Res. Coun.). H.M.S.O., London. 